\title{
Mechanism of Formation of Copper(II) Chloro Complexes Revealed by Transient Absorption Spectroscopy and DFT/TDDFT Calculations
}

\author{
Andrey S. Mereshchenko, ${ }^{*}{ }^{\dagger}$ Pavel K. Olshin, ${ }^{\dagger}$ Kanykey E. Karabaeva, ${ }^{\ddagger}$ Maxim S. Panov, ${ }^{\dagger}$ \\ R. Marshall Wilson, ${ }^{\dagger}$ Vladimir A. Kochemirovsky, ${ }^{\dagger}$ Mikhail Yu. Skripkin, ${ }^{\dagger}$ Yury S. Tveryanovich, ${ }^{\dagger}$ \\ and Alexander N. Tarnovsky \\ ${ }^{\dagger}$ Institute of Chemistry, Saint-Petersburg State University, 198504 Saint-Petersburg, Russian Federation \\ ${ }^{\ddagger}$ Department of Chemistry and the Center for Photochemical Sciences, Bowling Green State University, Bowling Green, Ohio 43403, \\ United States
}

\section{Supporting Information}

ABSTRACT: Copper(II) complexes are extremely labile with typical ligand exchange rate constants on the order of $10^{6}-10^{9} \mathrm{M}^{-1} \mathrm{~s}^{-1}$. As a result, it is often difficult to identify the actual formation mechanism of these complexes. In this work, using UV-vis transient absorption when probing in a broad time range $(20$ ps to $8 \mu \mathrm{s})$ in conjunction with DFT/TDDFT calculations, we studied the dynamics and underlying reaction mechanisms of the formation of extremely labile copper(II) $\mathrm{CuCl}_{4}{ }^{2-}$ chloro complexes from copper(II) $\mathrm{CuCl}_{3}{ }^{-}$trichloro complexes and chloride ions. These two species, produced via photochemical dissociation of $\mathrm{CuCl}_{4}{ }^{2-}$ upon $420 \mathrm{~nm}$ excitation into the ligand-to-metal-charge-transfer electronic state, are found to recombine into parent complexes with bimolecular rate constants of $(9.0 \pm 0.1) \times 10^{7}$ and $(5.3 \pm 0.4) \times 10^{8} \mathrm{M}^{-1} \mathrm{~s}^{-1}$ in acetonitrile and dichloromethane, respectively. In dichloromethane, recombination occurs via a simple one-step addition. In

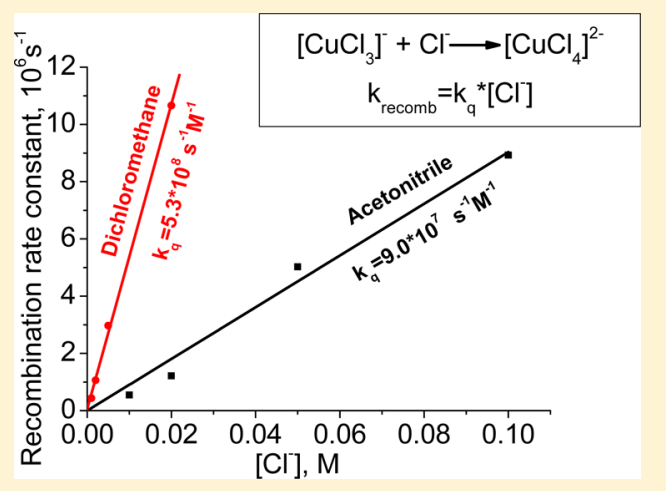
acetonitrile, where $\left[\mathrm{CuCl}_{3}\right]^{-}$reacts with the solvent to form a $\left[\mathrm{CuCl}_{3} \mathrm{CH}_{3} \mathrm{CN}\right]^{-}$complex in less than 20 ps, recombination takes place via ligand exchange described by the associative interchange mechanism that involves a $\left[\mathrm{CuCl}_{4} \mathrm{CH}_{3} \mathrm{CN}\right]^{2-}$ intermediate. In both solvents, the recombination reaction is potential energy controlled.

\section{INTRODUCTION}

It is well-known that copper plays an important role in metabolism of living organisms, for example, plastocyanin takes part as an electron donor species in the photosynthesis of the photosystem I in plants and bacteria. ${ }^{1}$ Electron and energy transport processes of this and several other copper-containing proteins have been the focus of many recent studies. ${ }^{2-4}$ In general, these transfer properties are associated with the ability of a copper ion to change its oxidation number reversibly. ${ }^{3}$ However, plastocyanin is a rather complicated system for studying the photoinduced transformation of the copper proteins. On the other hand, copper(II) chloro complexes are known as model compounds to understand the photochemistry of more complex copper species, and potentially, they can be useful for better understanding of copper proteins. ${ }^{5,6}$

One of the most important aspects of coordination chemistry is formation dynamics of metal complexes, which usually involves ligand substitution (or exchange) processes. This means that it is necessary to know the ligand exchange mechanism of metal complexes in various environments to better understand the reactivity of metal ions in biology and biochemistry. There is a number of studies describing ligand exchange processes in nonaqueous solutions ${ }^{7-9}$ and polymers, ${ }^{10}$ but the ligand exchange processes have been best studied in aqueous solutions. ${ }^{9,11-13}$ Substitution processes in nonaqueous media are of interest because of synthetic applications. Ligand substitution kinetics of transition metals, e.g., manganese, ${ }^{14}$ chromium, ${ }^{11}$ nickel, ${ }^{12}$ cadmium, ${ }^{15}$ and others, ${ }^{16}$ attract a great deal of attention and have been actively studied. Moreover, photoinduced structural rearrangements of metal complexes also raise a lot of interest. ${ }^{17}$ Depending on ligand exchange reaction rates, metal complexes are classified into two categories: ${ }^{18}$ inert complexes, where ligand exchange is slow (rate constants, $<10^{1}$ $\mathrm{M}^{-1} \mathrm{~s}^{-1}$ ) and labile complexes characterized by high ligand exchange rate constants $\left(>10^{2} \mathrm{M}^{-1} \mathrm{~s}^{-1}\right)$. Langford and Gray ${ }^{19}$ proposed classifying the mechanisms of ligand exchange reactions into associative, dissociative, and interchange mechanisms. The associative mechanism (A) involves the reaction intermediate species with the coordination number larger than that of the initial complex due to association with the incoming ligand. On the contrary, the dissociative mechanism (D) involves dissociation of a ligand with formation of the intermediate species, which coordination number is smaller than that of the initial complex. The case between these two extremes is the

Received: April 23, 2015

Revised: June 16, 2015

Published: June 16, 2015 
interchange mechanism (I) that usually proceeds through a manifold of transition states separating intermediate complexes, which cannot be kinetically detected. Interchange mechanisms range from associative interchange $\left(\mathrm{I}_{\mathrm{A}}\right)$, in which the bondmaking is of greater importance, to interchange (I), in which bond-making and bond-breaking processes are equally important, and to dissociative interchange in which bond-breaking is predominantly important $\left(\mathrm{I}_{\mathrm{D}}\right){ }^{7}$ The $\mathrm{A}, \mathrm{I}_{\mathrm{A}}$, and $\mathrm{I}_{\mathrm{D}}$ mechanisms are common for four-, ${ }^{8}$ five-, ${ }^{7}$ and six-coordinated ${ }^{9}$ copper(II) complexes, respectively.

The experimental kinetic data for copper complexes are extremely limited despite the fact that the thermodynamics of copper(II) ion complexation is studied rather well. ${ }^{20-24}$ The kinetics of a large number of stable, inert complexes of the transition metals can be studied by spectrophotometric methods. ${ }^{15}$ But, due to combination of Jahn-Taller distortion and fast reorientation of the distortion axis, copper(II) complexes are extremely labile with typical ligand exchange rate constants on the order of $10^{6}-10^{9} \mathrm{M}^{-1} \mathrm{~s}^{-1}, 7,9,25-27$ and as a consequence, conventional spectrophotometric methods fail to resolve the course of structural changes from reagents to products in copper(II) ligand exchange reactions.

High-pressure NMR spectroscopy is one of the most informative and useful methods for describing the exchange mechanism of labile complexes. ${ }^{28,29}$ The results obtained by NMR studies can be supported by quantum chemical calculations. ${ }^{11}$ For example, DFT, as one of the most reliable low-cost computation methods, ${ }^{30}$ allows us to evaluate the thermodynamics and structural changes during the course of the reaction, and thus, provides enough information to interpret the reaction mechanism. Another useful experimental method for measuring ligand exchange rates and establishing the involved reaction mechanism is temperature-jump ( $T$-jump) timeresolved transient mid-IR absorbance spectroscopy. ${ }^{13}$ This method is based on local ultrafast heating of the substance under investigation, resulting in the equilibrium shift from initial complexes to product complexes. The T-jump method has a significantly better time resolution $(5 \mathrm{ps})^{31}$ than NMR spectroscopy (several nanoseconds) and, therefore, is more suitable for studying ligand exchange reactions of extremely labile complexes such as copper(II) compounds. In this work, we demonstrate the power of studying the formation dynamics of very labile complexes by using picosecond and nanosecond UVvis transient absorption spectroscopies in conjunction with DFT calculations. For this study, we selected copper(II) tetrachloro complexes for several reasons. To begin with, photolysis of $\left[\mathrm{CuCl}_{4}\right]^{2-}$ results in ionic dissociation without any reduction of copper(II) ions, ${ }^{32,33}$ so that the subsequent recombination of ionic fragment species can be exclusively monitored using transient absorption spectroscopy. Next, this complex has a tractable size for quantum-chemical calculations. Also, $\left[\mathrm{CuCl}_{4}\right]^{2-}$ is soluble in both polar and nonpolar solvents, which makes it possible to study ligand substitution in solvents with different donor properties, i.e., different abilities of the solvent to coordinate to the metal ion (for example, dichloromethane and acetonitrile, which are characterized by donor numbers of 1 and $14.1,{ }^{34}$ respectively). A small size of a chloride ligand minimizes the role of steric effects in these reactions.

Herein, the photochemistry of $\left[\mathrm{CuCl}_{4}\right]^{2-}$ complexes is studied in two solvents of different donor properties, namely, dichloromethane and acetonitrile, by means of UV-vis transient absorption spectroscopy with probing from several picoseconds to several microseconds, and density functional theory (DFT) and time-dependent density functional theory (TDDFT) calculations. We focus on the recombination reactions of the ionic dissociation products assigned, on the basis of this work, to ligand exchange and ligand addition in acetonitrile and dichloromethane, respectively.

\section{EXPERIMENTAL AND COMPUTATIONAL METHODS}

Copper(II) perchlorate hexahydrate (98\%), tetraethylammonium chloride (>98\%), dichloromethane (HPLC grade, anhydrous), and acetonitrile ( $>99.5 \%$, anhydrous) were purchased from Sigma-Aldrich. Tetraethylammonium chloride was dried in a vacuum oven at $110^{\circ} \mathrm{C}$ for $10 \mathrm{~h}$. All experiments were performed in acetonitrile and dichloromethane. The series of solutions were prepared for nanosecond transient absorption experiments. In these solutions the concentration of copper(II) ions in the form of copper(II) perchlorate was kept constant at $0.1 \mathrm{mM}$ in both solvents. On the contrary, the concentration of chloride ions in a form of tetraethylammonium chloride was varied to be $10,20,50$, and $100 \mathrm{mM}$ in acetonitrile and 1,2,5, and $20 \mathrm{mM}$ in dichloromethane. The ion ratio affects the ligand substitution process; therefore, we changed the mole ratio of $\mathrm{Cu}(\mathrm{II}): \mathrm{Cl}^{-}$to study the kinetics of ligand exchange mechanism. For picosecond experiments, we prepared the separate solutions in acetonitrile and dichloromethane in which the concentrations of $\mathrm{Cu}$ (II) and $\mathrm{Cl}^{-}$were 0.5 and $100 \mathrm{mM}$, respectively. UV-visNIR-IR absorption spectra of the solutions were measured using a Varian Cary 50 UV-vis spectrophotometer. All spectroscopic measurements were performed at $21{ }^{\circ} \mathrm{C}$.

Picosecond transient absorption spectra were measured using the previously described setup based on a regeneratively amplified Ti:sapphire laser system $(800 \mathrm{~nm}, 100 \mathrm{fs}$, and 1 $\mathrm{kHz}$ ). ${ }^{32}$ An optical parametric amplifier (OPA) was used to generate $420 \mathrm{~nm}$ excitation ("pump") pulses with the energy of 9 $\mu \mathrm{J} \mathrm{pulse}^{-1}$. White-light continuum probe pulses in the $340-760$ spectral range were generated by focusing the $800 \mathrm{~nm}$ light into a $3 \mathrm{~mm}$ thick $\mathrm{CaF}_{2}$ window. The probe light was focused onto the sample to a $160 \mu \mathrm{m}$ diameter spot and overlapped at an angle of $6^{\circ}$ with the pump light focused to a $460 \mu \mathrm{m}$ diameter spot. Transient absorption kinetic traces were measured simultaneously within $274 \mathrm{~nm}$ spectral intervals using a spectrograph/ dual-diode (analyzing/reference) array detector. The polarization of the pump and probe light was set at the magic angle $\left(54.7^{\circ}\right)$ with respect to each other. The solutions were circulated through a $2 \mathrm{~mm}$ Spectrosil UV quartz flow cell.

Nanosecond transient absorption spectra were measured using a Proteus spectrometer (Ultrafast Systems) coupled with a nanosecond Nd:YAG laser/OPO system (Opotek, Vibrant LD 355 II, 410-2400 nm, $5 \mathrm{~ns}$, and $10 \mathrm{~Hz}$ ). The Proteus spectrometer was equipped with a $150 \mathrm{~W}$ Xe arc lamp (Newport) used as a probe-light source, a monochromator (Bruker Optics), and a Si photodiode (Thorlabs, DET 10A). The Nd:YAG laser/ OPO system was set up to generate $420 \mathrm{~nm}$ excitation ("pump") pulses with the energy of $3 \mathrm{~mJ}$ pulse $^{-1}$. Transient absorption signals were measured in the transverse geometry in which the probe was made to pass through a $1 \mathrm{~cm}$ path length quartz cell filled with the sample solution. The 1024 kinetic traces at a single probe wavelength were averaged and then analyzed using Origin 9.0 software.

The geometries of the following species were optimized using DFT (B3LYP/6-31G(d)/PCM level of theory): $\left[\mathrm{CuCl}_{4}\right]^{2-}$ and $\left[\mathrm{CuCl}_{3}\right]^{-}$(in acetonitrile and dichloromethane), $\mathrm{CH}_{3} \mathrm{CN}$, $\left[\mathrm{CuCl}_{3} \mathrm{CH}_{3} \mathrm{CN}\right]^{-}$, and $\left[\mathrm{CuCl}_{4} \mathrm{CH}_{3} \mathrm{CN}\right]^{2-}$ (acetonitrile only), and $\left(\mathrm{NEt}_{4}\right)_{2} \mathrm{CuCl}_{4}$ and $\mathrm{NEt}_{4} \mathrm{CuCl}_{3}$ (dichloromethane only). 
Polarizable continuum model (PCM) was implemented to simulate solvent media, acetonitrile and dichloromethane. For the optimized geometries of the aforementioned $\mathrm{Cu}$ (II) species, vertical excitation transition (VET) energies were calculated using TDDFT (B3LYP/6-31G(d)). To find the energy profile of the reactions between copper(II) tricloro complexes and chloride ions, relaxed redundant scans along $\mathrm{Cu}-\mathrm{Cl}$ and $\mathrm{Cu}-$ $\mathrm{N}$ bonds were performed for $\left[\mathrm{CuCl}_{4}\right]^{2-},\left[\mathrm{CuCl}_{3} \mathrm{CH}_{3} \mathrm{CN}\right]^{-}$, and $\left[\mathrm{CuCl}_{4} \mathrm{CH}_{3} \mathrm{CN}\right]^{2-}$ complexes. A relaxed redundant scan along a $\mathrm{Cu}\left(\mathrm{CuCl}_{3}^{-}\right)-\mathrm{Cl}\left(\mathrm{CH}_{2} \mathrm{Cl}_{2}\right)$ bond was performed to locate the minimum energy geometry of the $\left[\mathrm{CuCl}_{3} \mathrm{CH}_{2} \mathrm{Cl}_{2}\right]^{-}$complex. All calculations were performed using Gaussian 09 software package. $^{35}$

\section{RESULTS}

Steady-State Absorption Spectroscopy. In this study, $\left[\mathrm{CuCl}_{4}\right]^{2-}$ complexes were obtained by addition of an excess of tetraethylammonium chloride to copper(II) perchlorate solutions. Acetonitrile and dichloromethane solutions containing $0.5 \mathrm{mM} \mathrm{Cu}\left(\mathrm{ClO}_{4}\right)_{2}$ and $100 \mathrm{mM} \mathrm{NEt}_{4} \mathrm{Cl}$ have all copper(II) ions existing in the form of $\left[\mathrm{CuCl}_{4}\right]^{2-}, 32,33$ exhibiting steady-state absorption spectra due to transitions in this species, Figure 1. The

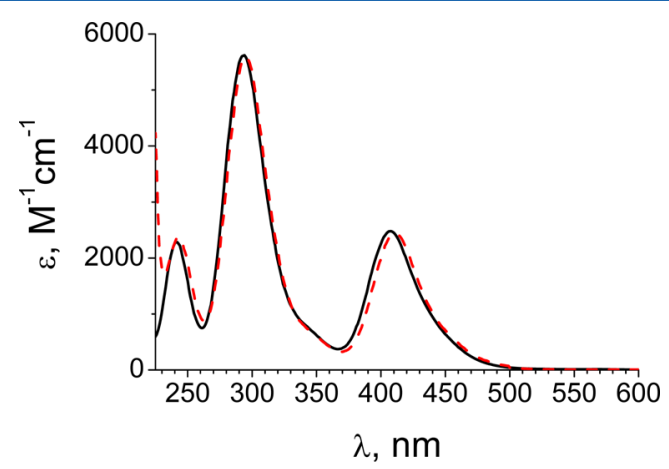

Figure 1. Steady-state absorption spectra of $\left[\mathrm{CuCl}_{4}\right]^{2-}$ complexes in acetonitrile (solid line) and dichloromethane (dashed line).

intense UV-vis absorption bands of $\left[\mathrm{CuCl}_{4}\right]^{2-}$ correspond to ligand-to-metal charge-transfer (LMCT) transitions. ${ }^{20,21,32,36,37}$ The shape and position of the LMCT bands are observed to be similar for acetonitrile and dichloromethane with only a small spectral shift of the absorption maxima. Steady-state absorption spectra of other solutions used in the nanosecond experiments demonstrate that the majority of copper(II) exists in the form of $\left[\mathrm{CuCl}_{4}\right]^{2-}$ complexes (Figure $1 \mathrm{~S}$ and $2 \mathrm{~S}$, Supporting Information).

Picosecond Transient Absorption Spectroscopy. For the picosecond transient absorption $(\Delta A)$ measurements, we used solutions containing $0.5 \mathrm{mM} \mathrm{Cu}\left(\mathrm{ClO}_{4}\right)_{2}$ and $100 \mathrm{mM}$ $\mathrm{NEt}_{4} \mathrm{Cl}$ in acetonitrile and dichloromethane. Upon $420 \mathrm{~nm}$ excitation, $\left[\mathrm{CuCl}_{4}\right]^{2-}$, the predominant form in these solutions, is promoted into the LMCT excited state. Then, the minor fraction of the LMCT-excited complex undergoes ionic dissociation whereas the major one returns to the ground state via internal conversion, which involves the relaxation to the vibrationally hot ground and ligand-field exited states. The lifetime of LMCT excited state is less than $500 \mathrm{fs}$ and the short-time transient absorption spectra $(0.5-20 \mathrm{ps})$ of $\left[\mathrm{CuCl}_{4}\right]^{2-}$ are dominated by the absorption of ligand-field excited states. ${ }^{32,33}$ The ligand-field excited states have a lifetime less than 5 ps, and therefore, they fully decay at 20 ps after excitation. Starting from 20 ps, the

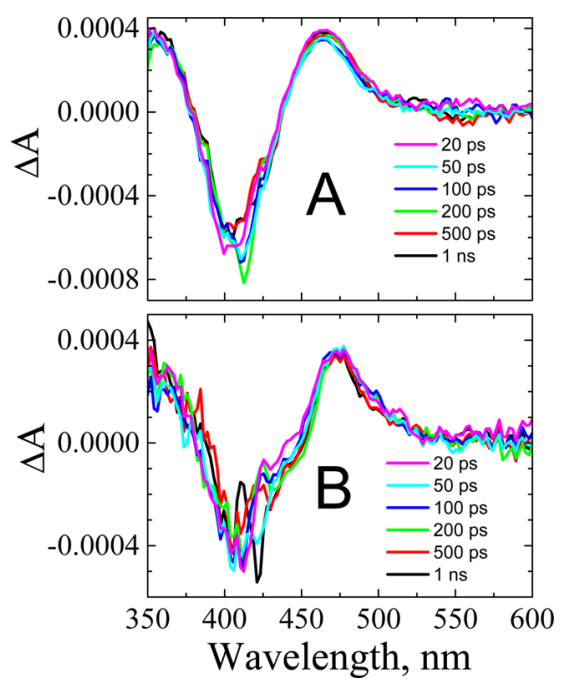

Figure 2. Picosecond transient absorption spectra of $\left[\mathrm{CuCl}_{4}\right]^{2-}$ complexes in acetonitrile (panel A) and dichloromethane (panel B) following $420 \mathrm{~nm}$ excitation $\left(0.5 \mathrm{mM} \mathrm{Cu}\left(\mathrm{ClO}_{4}\right)_{2}-100 \mathrm{mM} \mathrm{NEt}_{4} \mathrm{Cl}\right)$. Delay times between $420 \mathrm{~nm}$ excitation and probe pulses are shown in the legends.

transient absorption spectra do not change in both the solvents investigated over the full delay time range $(1 \mathrm{~ns})$ employed in these experiments, Figure 2 . In acetonitrile, these $\Delta A$ spectra consisting of the $350-380$ and $465 \mathrm{~nm} \Delta A$ bands (induced absorption) and the negative bleach centered at $405 \mathrm{~nm}$ were previously assigned $^{32,33}$ to the formation of copper(II) trichloro complexes, the product of ionic dissociation:

$$
\left[\mathrm{Cu}^{\mathrm{II}} \mathrm{Cl}_{4}\right]^{2-} \stackrel{420 \mathrm{~nm}}{\longrightarrow}\left[\mathrm{Cu}^{\mathrm{II}} \mathrm{Cl}_{3}\right]^{-}+\mathrm{Cl}^{-}
$$

The $\Delta A$ spectra of $\left[\mathrm{CuCl}_{4}\right]^{2-}$ in dichloromethane in the $20 \mathrm{ps}$ to $1 \mathrm{~ns}$ time range are similar to those in acetonitrile and, therefore, can also be assigned to the formation of copper(II) trichloro complexes.

Nanosecond Transient Absorption Spectroscopy. For the nanosecond transient absorption measurements, we used solutions containing $0.1 \mathrm{mM} \mathrm{Cu}\left(\mathrm{ClO}_{4}\right)_{2}$ and $x \mathrm{mM} \mathrm{NEt}_{4} \mathrm{Cl}$ (where $x$ varies from 10 to 100 in acetonitrile and from 1 to 20 in dichloromethane), Figures 3-5. At $50 \mathrm{~ns}$ after $420 \mathrm{~nm}$ excitation of acetonitrile and dichloromethane solutions, the $\Delta A$ spectra are found to be similar, consisting of the $350-380 \mathrm{~nm}$ feature, the $465 \mathrm{~nm} \Delta A$ band (shifted to $470 \mathrm{~nm}$ in dichloromethane), and the $405 \mathrm{~nm}$ negative bleach (Figure 3 ). The induced absorption bands decays to zero concurrently with recovery of the groundstate bleach and without any spectral reshaping. The decay of the $\Delta A$ bands is single-exponential, $\Delta A(t)=\Delta A_{0} \cdot \mathrm{e}^{-k_{\text {obs }} t}$ (Figure 4 and $5)$, where the pseudo-first-order rate constant $\left(k_{\mathrm{obs}}\right)$ is found to linearly depend on the concentration of $\mathrm{NEt}_{4} \mathrm{Cl}, k_{\mathrm{obs}}=k_{\mathrm{q}}$. $\left[\mathrm{NEt}_{4} \mathrm{Cl}\right]$, Figure 6 . On the basis of the $k_{\text {obs }}$ values resulting from these single-exponential fits, the bimolecular rate constants, $k_{\mathrm{q}}$, are evaluated to be $(9.0 \pm 0.1) \times 10^{7}$ and $(5.3 \pm 0.4) \times 10^{8} \mathrm{M}^{-1}$ $\mathrm{s}^{-1}$ in acetonitrile and dichloromethane, respectively. The nanosecond and picosecond $\Delta A$ spectra upon $420 \mathrm{~nm}$ excitation of $\left[\mathrm{CuCl}_{4}\right]^{2-}$ are identical, which suggests the formation of the copper(II) trichloro complex product in both experiments. The complete decay of the $\Delta A$ bands accompanied by the groundstate bleach recovery is assigned to recombination of copper(II) trichloro complexes and chloride ions into parent $\left[\mathrm{CuCl}_{4}\right]^{2-}$ complexes. 


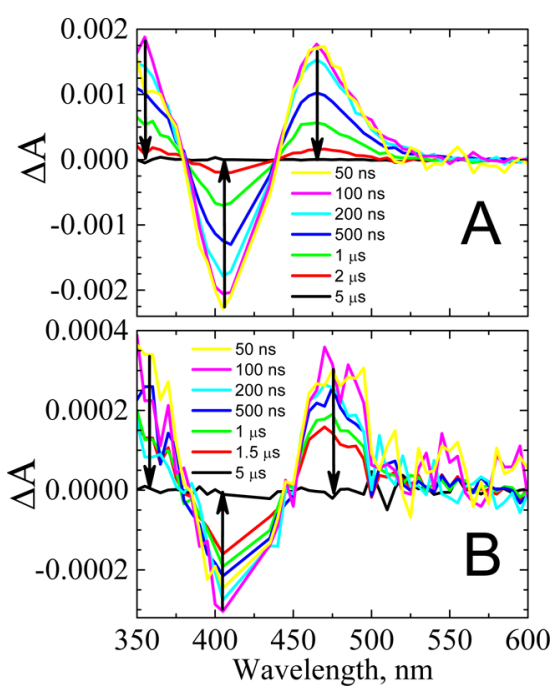

Figure 3. Nanosecond transient absorption spectra of $\mathrm{CuCl}_{4}^{2-}$ complexes in acetonitrile $\left(0.1 \mathrm{mM} \mathrm{Cu}\left(\mathrm{ClO}_{4}\right)_{2}-20 \mathrm{mM} \mathrm{NEt}_{4} \mathrm{Cl}\right.$, panel A) and dichloromethane $\left(0.1 \mathrm{mM} \mathrm{Cu}\left(\mathrm{ClO}_{4}\right)_{2}-1 \mathrm{mM} \mathrm{NEt}_{4} \mathrm{Cl}\right.$, panel B) after $420 \mathrm{~nm}$ excitation. Delay times are shown in the legends.

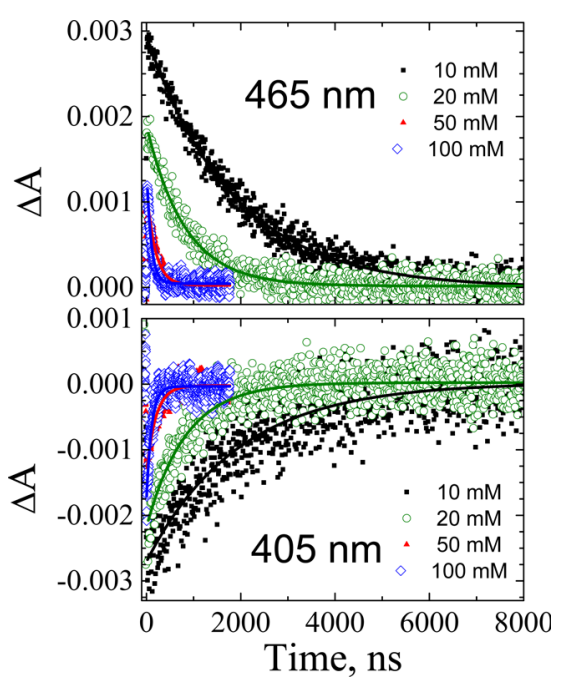

Figure 4. Nanosecond transient absorption kinetic traces (symbols) of $0.1 \mathrm{mM} \mathrm{Cu}\left(\mathrm{ClO}_{4}\right)_{2}$ and $x \mathrm{mM} \mathrm{NEt}_{4} \mathrm{Cl}(x=10,20,50$, and 100 as shown in the legends) acetonitrile solutions measured at probe wavelengths of 465 and $405 \mathrm{~nm}$ after $420 \mathrm{~nm}$ excitation. Single-exponential fits, $\Delta A(t)=$ $\Delta A_{0} \cdot \mathrm{e}^{-k_{\mathrm{obs}} \mathrm{t}}$, are shown as lines.

Diffusion-Controlled Rate Constants. Diffusion-controlled rate constants, $k_{\mathrm{D}}$, for the possible reactions between copper(II) chloro complexes were estimated using Smoluchowski relationship for neutral species and Debye theory for ions, ${ }^{27,38}$ Table 1. The details of these calculations are given in the Supporting Information.

Calculations. The energy profiles for recombination of copper(II) trichloro complexes and chloride ions into copper(II) tetrachloro complexes are calculated for several reaction mechanisms. The product of ionic dissociation, $\mathrm{CuCl}_{3}{ }^{-}$, exists in acetonitrile as a tetracoorinated solvato complex, $\left[\mathrm{CuCl}_{3} \mathrm{CH}_{3} \mathrm{CN}\right]^{-}$, which has $D_{2 d}$ local symmetry. ${ }^{20,24}$ Two reaction mechanisms are proposed for recombination (eq 2) of a $\left[\mathrm{CuCl}_{3} \mathrm{CH}_{3} \mathrm{CN}\right]^{-}$complex and $\mathrm{a} \mathrm{Cl}^{-}$ion in acetonitrile: dissociative (eqs 3a,b) and associative (eqs 4a,b). Relaxed scans along the $\mathrm{Cu}-\mathrm{Cl}$ bond of $\left[\mathrm{CuCl}_{4}\right]^{2-}$ and

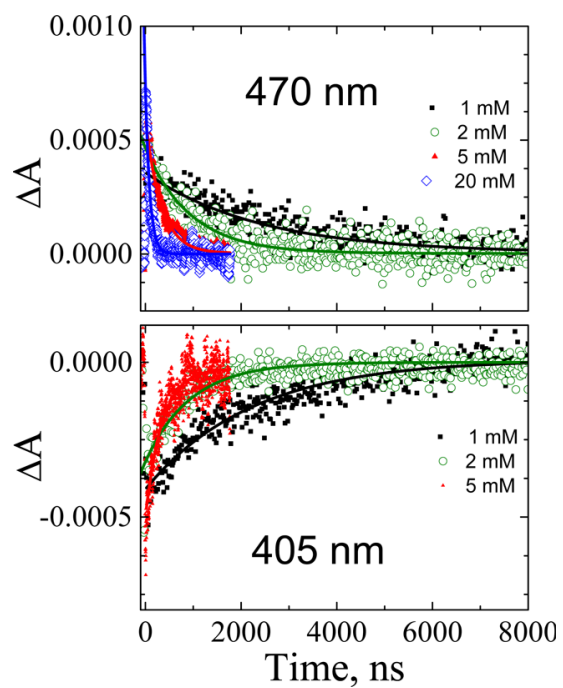

Figure 5. Nanosecond transient absorption kinetic traces (symbols) of $0.1 \mathrm{mM} \mathrm{Cu}\left(\mathrm{ClO}_{4}\right)_{2}$ and $x \mathrm{mM} \mathrm{NEt}_{4} \mathrm{Cl}(x=1,2,5$, and 20$)$ dichloromethane solutions measured at probe wavelengths of 470 and $405 \mathrm{~nm}$ after $420 \mathrm{~nm}$ excitation. Single-exponential fits, $\Delta A(t)=\Delta A_{0}$. $\mathrm{e}^{-k_{\text {obs }} t}$, are shown as lines. The $405 \mathrm{~nm}$ kinetic trace for the $0.1 \mathrm{mM}$ $\mathrm{Cu}\left(\mathrm{ClO}_{4}\right)_{2}-20 \mathrm{mM} \mathrm{NEt}_{4} \mathrm{Cl}$ solution is not shown due to significant signals from the scattered excitation light at short times.

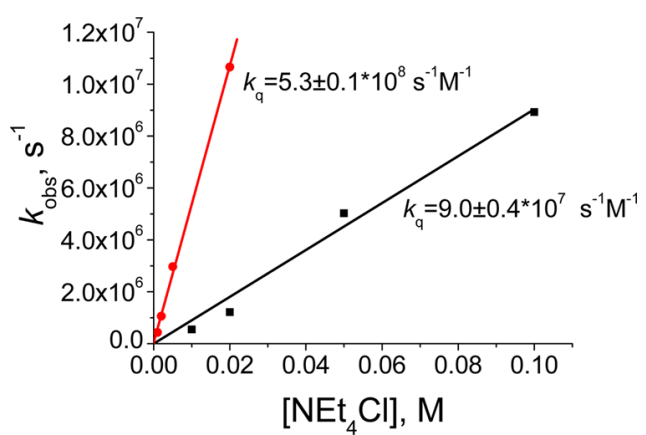

Figure 6. Observed pseudo-first-order rate constants $\left(k_{\mathrm{obs}}\right)$ plotted as a function of the concentration of $\mathrm{NEt}_{4} \mathrm{Cl}\left(\left[\mathrm{NEt}_{4} \mathrm{Cl}\right]\right)$ in acetonitrile (squares) and dichloromethane (circles). The lines are the linear fits of the $k_{\mathrm{obs}}$ values according to the equation: $k_{\mathrm{obs}}=k_{\mathrm{q}} \cdot\left[\mathrm{NEt}_{4} \mathrm{Cl}\right]$, where $k_{\mathrm{q}}$ are the bimolecular rate constant. The resulting $k_{\mathrm{q}}$ values are equal to $(9.0 \pm 0.1) \times 10^{7}$ and $(5.3 \pm 0.4) \times 10^{8} \mathrm{M}^{-1} \mathrm{~s}^{-1}$ in acetonitrile and dichloromethane, respectively.

Table 1. Estimated Values of Diffusion-Controlled Rate Constants, $k_{\mathrm{D}}, \mathrm{M}^{-1} \mathrm{~s}^{-1}$

\begin{tabular}{lll}
\multicolumn{1}{c}{ reaction } & acetonitrile & dichloromethane \\
$\mathrm{NEt}_{4} \mathrm{CuCl}_{3}+\mathrm{NEt}_{4} \mathrm{Cl}=\left(\mathrm{NEt}_{4}\right)_{2} \mathrm{CuCl}_{4}$ & N/A & $1.6 \times 10^{10}$ \\
$2 \mathrm{NEt}_{4} \mathrm{CuCl}_{3}=\left(\mathrm{NEt}_{4}\right)_{2} \mathrm{Cu}_{2} \mathrm{Cl}_{6}$ & N/A & $1.6 \times 10^{10}$ \\
$2 \mathrm{CuCl}_{3}^{-}=\mathrm{Cu}_{2} \mathrm{Cl}_{6}^{2-}$ & $7.8 \times 10^{9}$ & $2.4 \times 10^{9}$ \\
{$\left[\mathrm{CuCl}_{3}\right]^{-}+\mathrm{Cl}^{-}=\left[\mathrm{CuCl}_{4}\right]^{2-}$} & $8.3 \times 10^{9}$ & $2.5 \times 10^{9}$ \\
{$\left[\mathrm{CuCl}_{3} \mathrm{CH}_{3} \mathrm{CN}\right]^{-}+\mathrm{Cl}^{-}=\left[\mathrm{CuCl}_{4} \mathrm{CH}_{3} \mathrm{CN}\right]^{2-}$} & $6.5 \times 10^{9}$ & N/A \\
\hline
\end{tabular}

$\left[\mathrm{CuCl}_{4} \mathrm{CH}_{3} \mathrm{CN}\right]^{2-}$ complexes, as well as along the $\mathrm{Cu}-\mathrm{N}$ bond of $\left[\mathrm{CuCl}_{3} \mathrm{CH}_{3} \mathrm{CN}\right]^{-}$and $\left[\mathrm{CuCl}_{4} \mathrm{CH}_{3} \mathrm{CN}\right]^{2-}$ were performed to explore these two mechanisms, Figures 7 and 8 . The resulting values of potential energy barriers, $E_{a}$ are shown below.

$$
\left[\mathrm{CuCl}_{3} \mathrm{CH}_{3} \mathrm{CN}\right]^{-}+\mathrm{Cl}^{-}=\left[\mathrm{CuCl}_{4}\right]^{2-}+\mathrm{CH}_{3} \mathrm{CN}
$$




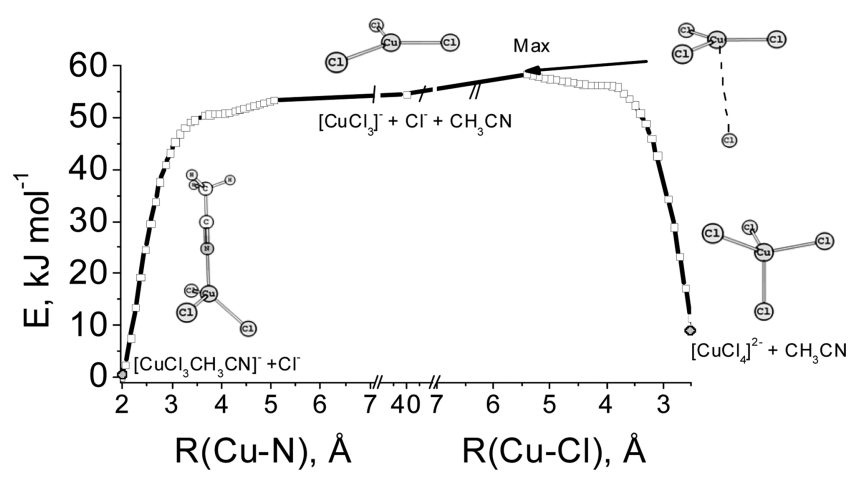

Figure 7. Relaxed redundant coordinate scans along the $\mathrm{Cu}-\mathrm{N}$ bond of $\left[\mathrm{CuCl}_{3} \mathrm{CH}_{3} \mathrm{CN}\right]^{-}$and along the $\mathrm{Cu}-\mathrm{Cl}$ bond of $\left[\mathrm{CuCl}_{4}\right]^{2-}$ in acetonitrile, which explore the dissociative mechanism (eqs $3 a, b)$ of the recombination reaction (eq 2). The structures corresponding to the $\left[\mathrm{CuCl}_{3} \mathrm{CH}_{3} \mathrm{CN}\right]^{-},\left[\mathrm{CuCl}_{3}\right]^{-}$, and $\left[\mathrm{CuCl}_{4}\right]^{2-}$ energy minima and the barrier top (Max) are shown.

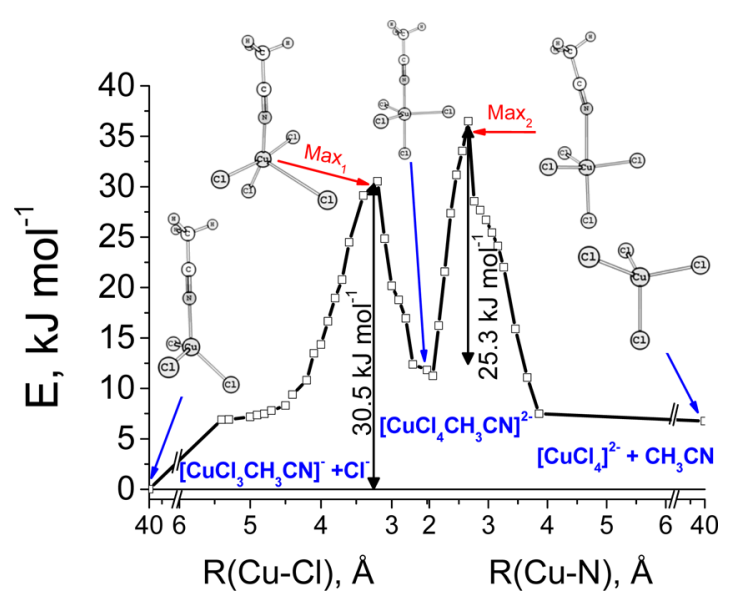

Figure 8. Relaxed redundant coordinate scans along the $\mathrm{Cu}-\mathrm{Cl}$ and $\mathrm{Cu}-\mathrm{N}$ bonds of the $\left[\mathrm{CuCl}_{4} \mathrm{CH}_{3} \mathrm{CN}\right]^{2-}$ complex in acetonitrile exploring the associative mechanism (eqs $4 \mathrm{a}, \mathrm{b}$ ) of the recombination reaction (eq 2). The structures corresponding to the $\left[\mathrm{CuCl}_{3} \mathrm{CH}_{3} \mathrm{CN}\right]^{-}$, $\left[\mathrm{CuCl}_{4} \mathrm{CH}_{3} \mathrm{CN}\right]^{2-}$, and $\left[\mathrm{CuCl}_{4}\right]^{2-}$ energy minima and the energy maxima $\left(\operatorname{Max}_{1}\right.$ and $\left.\mathrm{Max}_{2}\right)$ are shown.

$$
\begin{aligned}
& {\left[\mathrm{CuCl}_{3} \mathrm{CH}_{3} \mathrm{CN}\right]^{-} \rightarrow\left[\mathrm{CuCl}_{3}\right]^{-}+\mathrm{CH}_{3} \mathrm{CN} \quad E_{\mathrm{a}}=54.5 \mathrm{~kJ} \mathrm{~mol}^{-1}} \\
& {\left[\mathrm{CuCl}_{3}\right]^{-}+\mathrm{Cl}^{-} \rightarrow\left[\mathrm{CuCl}_{4}\right]^{2-} \quad E_{\mathrm{a}}=3.9 \mathrm{~kJ} \mathrm{~mol}^{-1}} \\
& {\left[\mathrm{CuCl}_{3} \mathrm{CH}_{3} \mathrm{CN}\right]^{-}+\mathrm{Cl}^{-} \rightarrow\left[\mathrm{CuCl}_{4} \mathrm{CH}_{3} \mathrm{CN}\right]^{2-} \quad E_{\mathrm{a}}=30.5 \mathrm{~kJ} \mathrm{~mol}{ }^{-1}}
\end{aligned}
$$

$$
\left[\mathrm{CuCl}_{4} \mathrm{CH}_{3} \mathrm{CN}\right]^{2-} \rightarrow\left[\mathrm{CuCl}_{4}\right]^{2-}+\mathrm{CH}_{3} \mathrm{CN} \quad E_{\mathrm{a}}=25.3 \mathrm{~kJ} \mathrm{~mol}^{-1}
$$

We found that in the dissociative mechanism, the rate-liming step is dissociation of $\left[\mathrm{CuCl}_{3} \mathrm{CH}_{3} \mathrm{CN}\right]^{-}$into a $\left[\mathrm{CuCl}_{3}\right]^{-}$complex and an acetonitrile molecule (eq $3 \mathrm{a}$ ). This step is characterized by the potential energy barrier of $54.5 \mathrm{~kJ} \mathrm{~mol}^{-1}$. In the associative mechanism, the rate-liming step is the reaction between a $\left[\mathrm{CuCl}_{3} \mathrm{CH}_{3} \mathrm{CN}\right]^{-}$complex and a chloride ion characterized by the potential energy barrier of $30.5 \mathrm{~kJ} \mathrm{~mol}^{-1}$. This energy barrier is significantly lower than that for the dissociative mechanism. Therefore, according to the DFT calculations, the ligand exchange reaction (eq 2) proceeds through the associative mechanism (eqs $4 a, b)$.
The actual form of a $\mathrm{CuCl}_{3}^{-}$complex is controversial in dichloromethane. We considered three possible forms: $\left[\mathrm{CuCl}_{3}\right]^{-},\left[\mathrm{CuCl}_{3} \mathrm{CH}_{2} \mathrm{Cl}_{2}\right]^{-}$, and $\left[\mathrm{Cu}_{2} \mathrm{Cl}_{6}\right] \cdot{ }^{19,39}$ The relaxed scan along the $\mathrm{Cu}\left(\mathrm{CuCl}_{3}^{-}\right)-\mathrm{Cl}\left(\mathrm{CH}_{2} \mathrm{Cl}_{2}\right)$ bond (Figure 9)

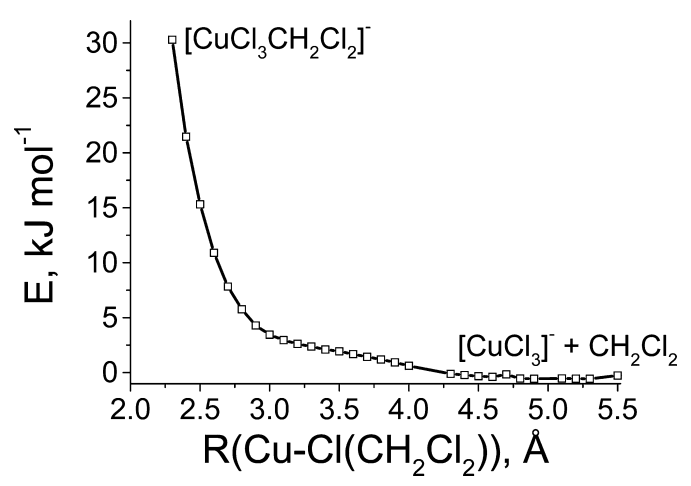

Figure 9. Relaxed redundant coordinate scan along the $\mathrm{Cu}-$ $\mathrm{Cl}\left(\mathrm{CH}_{2} \mathrm{Cl}_{2}\right)$ bond in $\left[\mathrm{CuCl}_{3} \mathrm{CH}_{2} \mathrm{Cl}_{2}\right]^{-}$demonstrates that the $\mathrm{Cu}$ $\mathrm{CH}_{2} \mathrm{Cl}_{2}$ interaction is repulsive and, as a result, the $\left[\mathrm{CuCl}_{3} \mathrm{CH}_{2} \mathrm{Cl}_{2}\right]^{-}$ form of $\mathrm{CuCl}_{3}^{-}$is unfavorable.

demonstrates that the $\mathrm{Cu}-\mathrm{CH}_{2} \mathrm{Cl}_{2}$ interaction in the $\left[\mathrm{CuCl}_{3} \mathrm{CH}_{2} \mathrm{Cl}_{2}\right]^{-}$complex is repulsive, and therefore, one can conclude that the $\left[\mathrm{CuCl}_{3} \mathrm{CH}_{2} \mathrm{Cl}_{2}\right]^{-}$form of the $\mathrm{CuCl}_{3}{ }^{-}$complex is unfavorable. We did not observe the formation of the $\mathrm{CuCl}_{3}{ }^{-}$ dimer, $\left[\mathrm{Cu}_{2} \mathrm{Cl}_{6}\right]^{2-}$, over the about $10 \mu$ s time scale investigated. Indeed, for dimerization of free and ion-pair copper(II) trichloro complexes, $\mathrm{CuCl}_{3}^{-}$and $\mathrm{NEt}_{4} \mathrm{CuCl}_{3}$, diffusion-controlled rate constants, $k_{\mathrm{d}}$ are estimated to be $2.4 \times 10^{9}$ and $1.6 \times 10^{10} \mathrm{M}^{-1} \mathrm{~s}^{-1}$, respectively, resulting in the fastest reaction times of about 4 and $0.6 \mu \mathrm{s}$ for the $0.1 \mathrm{mM}$ copper(II) concentration used. However, in the nanosecond transient absorption experiment (Figure 3), we observed single-exponential decays of the $\Delta A$ signals without any spectral shape change up to $8 \mu \mathrm{s}$, which is suggestive of relaxation involving a single form of the copper(II) trichloro complex. Two other possibilities are that in dichloromethane a copper(II) trichloro complex exists as a tricoordinated complex, either $\mathrm{CuCl}_{3}{ }^{-}$or $\mathrm{NEt}_{4} \mathrm{CuCl}_{3}$. Our calculations demonstrate that the chlorine coordination sphere of $\mathrm{CuCl}_{3}{ }^{-}$is not affected when this complex is approached by $\mathrm{NEt}_{4}{ }^{+}$. Therefore, to simplify our calculations, we performed the relaxed scan along the $\mathrm{Cu}-\mathrm{Cl}$ bond coordinate of the $\left[\mathrm{CuCl}_{4}\right]^{2-}$ complex to compute the potential energy profile of the recombination reaction of $\left[\mathrm{CuCl}_{3}\right]^{-}$and chloride ions, eq 5 .

$$
\left[\mathrm{CuCl}_{3}\right]^{-}+\mathrm{Cl}^{-} \rightarrow\left[\mathrm{CuCl}_{4}\right]^{2-} \quad E_{\mathrm{a}}=25.0 \mathrm{~kJ} \mathrm{~mol}^{-1}
$$

The potential energy barrier of this recombination reaction is computed to be equal to $25.0 \mathrm{~kJ} \mathrm{~mol}^{-1}$. Figure 10 shows the computed energy profile.

\section{DISCUSSION}

Forms of the Complexes. As shown in the previous studies, a $\left[\mathrm{CuCl}_{4}\right]^{2-}$ complex has $\mathrm{D}_{2 d}$ local symmetry in acetonitrile, ${ }^{20,21,36,37}$ corresponding to the geometry intermediate between square planar and tetrahedral. Because of the significant similarities between absorption spectra of $\left[\mathrm{CuCl}_{4}\right]^{2-}$ in acetonitrile and dichloromethane (Figure 1), this complex can be assumed to have $D_{2 d}$ local symmetry in dichloromethane as well. Our DFT calculations further support $D_{2 d}$ local symmetry of $\left[\mathrm{CuCl}_{4}\right]^{2-}$ in acetonitrile and dichloromethane (Figures 8 and 


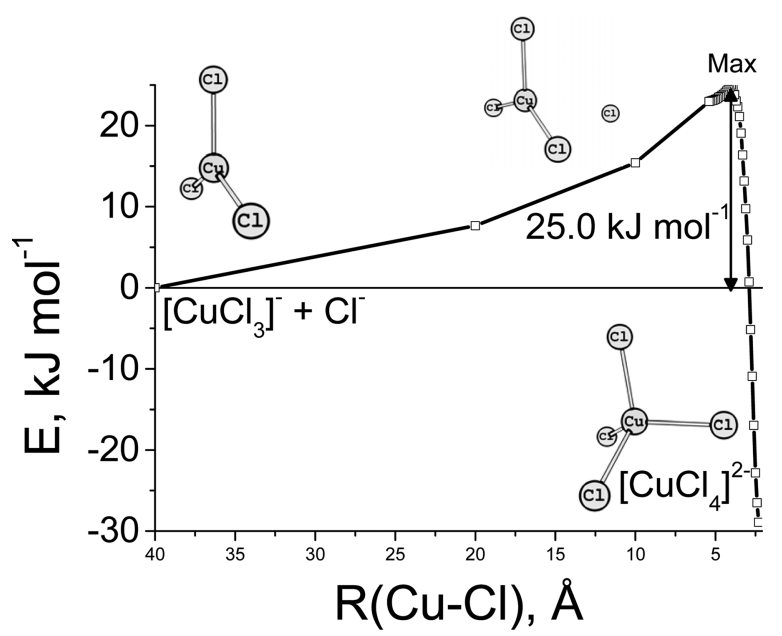

Figure 10. Relaxed redundant coordinate scan along the along $\mathrm{Cu}-\mathrm{Cl}$ bond for $\left[\mathrm{CuCl}_{4}\right]^{2-}$ in dichloromethane explores the proposed recombination reaction mechanism (eq 5 ). The structures corresponding to the energy $\left(\left[\mathrm{CuCl}_{3}\right]^{-}\right.$and $\left.\left[\mathrm{CuCl}_{4}\right]^{2-}\right)$ minima and maximum (Max) are shown.

10, Tables 3 and 4). Nevertheless, the solvation of $\left[\mathrm{CuCl}_{4}\right]^{2-}$ is likely to be different in these two solvents. In polar acetonitrile, $\left[\mathrm{CuCl}_{4}\right]^{2-}$ is solvated by solvent molecules. ${ }^{20,21}$ In significantly less polar dichloromethane, $\left[\mathrm{CuCl}_{4}\right]^{2-}$ is surrounded by two tetraethylammonium counterions and exist in the form of $\left(\mathrm{NEt}_{4}{ }^{+}\right)_{2}\left(\mathrm{CuCl}_{4}{ }^{2-}\right)$, by analogy with $\left(\mathrm{N}_{(}\left(\mathrm{C}_{6} \mathrm{H}_{13}\right)_{4}{ }^{+}\right)_{2}\left(\mathrm{CuCl}_{4}{ }^{2-}\right)$ in chlorobenzene. ${ }^{40}$ The ionic dissociation product, $\mathrm{CuCl}_{3}{ }^{-}$, exists in acetonitrile as the tetracoordinated $\left[\mathrm{CuCl}_{3} \mathrm{CH}_{3} \mathrm{CN}\right]^{-}$ solvato complex, which has $D_{2 d}$ local symmetry. ${ }^{20,24}$ A dichloromethane molecule is a weak electron donor and, therefore, is unlikely to coordinate to the copper(II) metal center. As a result, the trichlorocopper(II) complex is tricoordinated in dichloromethane. The DFT calculations support this conclusion, Figure 9. By analogy with $\left[\mathrm{CuCl}_{4}\right]^{2-}$, we propose that in the dichloromethane solutions investigated, the $\mathrm{CuCl}_{3}{ }^{-}$complex exists as the $\left(\mathrm{NEt}_{4}{ }^{+}\right)\left(\mathrm{CuCl}_{3}{ }^{-}\right)$ion pair. For these two species, the DFT calculations suggest that the local geometry of the copper(II) ion is trigonal planar. Furthermore, the calculations demonstrate that the geometry of the first coordination sphere is the same for the free $\mathrm{CuCl}_{3}{ }^{-}$and $\mathrm{CuCl}_{4}{ }^{2-}$ complexes and the $\left(\mathrm{NEt}_{4}^{+}\right)\left(\mathrm{CuCl}_{3}^{-}\right)$and $\left(\mathrm{NEt}_{4}^{+}\right)_{2}\left(\mathrm{CuCl}_{4}^{2-}\right)$ ion pairs. This is probably why the TDDFT VET energies computed for $\left[\mathrm{CuCl}_{3} \mathrm{CH}_{3} \mathrm{CN}\right]^{-}$and $\left(\mathrm{NEt}_{4}{ }^{+}\right)\left(\mathrm{CuCl}_{3}{ }^{-}\right)$are similar. The level of the TDDFT theory used is adequate because the VET energies of $\left[\mathrm{CuCl}_{3} \mathrm{CH}_{3} \mathrm{CN}\right]^{-}$and $\left(\mathrm{NEt}_{4}{ }^{+}\right)$$\left(\mathrm{CuCl}_{3}^{-}\right)$products agree with the spectral positions of the transient absorption bands, and the VET energies of parent $\left[\mathrm{CuCl}_{4}\right]^{2-}$ and $\left(\mathrm{NEt}_{4}{ }^{+}\right)_{2}\left(\mathrm{CuCl}_{4}{ }^{2-}\right)$ tetrachloro complexes agree with the steady-state spectra, Figure 1 and Table 2 . Similarly to copper(II) chloro complexes, tetraethylammonium chloride species, which are the source of chloride ions, are present as $\mathrm{NEt}_{4}{ }^{+} \mathrm{Cl}^{-}$ion pairs in dichloromethane solutions and as fully separated ions in acetonitrile solutions (association constants, $K_{\mathrm{a}}$ $=12$ and $92000 \mathrm{M}^{-1}$ in acetonitrile ${ }^{41}$ and dichloromethane, ${ }^{42}$ respectively). The complete dissociation of $\mathrm{NEt}_{4} \mathrm{Cl}$ in acetonitrile is confirmed by the linear dependence of the chloride ion absorbance at $215 \mathrm{~nm}$ on the concentration of this salt (Figure 3S, Supporting Information).

Reaction Mechanism. In a number of studies, ${ }^{32,33,40,43,44}$ it was shown by means of steady-state photolysis, actinometry, and transient absorption techniques that important relaxation channels of the LMCT excited states of $\left[\mathrm{CuCl}_{4}\right]^{2-}$ complexes

Table 2. Energies (in nm) of Electronic Transitions Observed in the Steady-State and Transient Absorption Spectra as Well as Calculated (B3LYP//B3LYP/6-31G(d)/PCM, Acetonitrile and Dichloromethane Parameters) for the Copper(II) Tri- and Tetrachloro Complexes ${ }^{a}$

\begin{tabular}{|c|c|c|c|c|c|}
\hline $\mathrm{CuCl}_{4}{ }^{2-}$ in $\mathrm{CH}_{3} \mathrm{CN}$ & $\mathrm{CuCl}_{4}{ }^{2-}$ in $\mathrm{CH}_{2} \mathrm{Cl}_{2}$ & $\left(\mathrm{NEt}_{4}\right)_{2} \mathrm{CuCl}_{4}$ in $\mathrm{CH}_{2} \mathrm{Cl}_{2}$ & $\mathrm{CuCl}_{3} \mathrm{CH}_{3} \mathrm{CN}^{-}$in $\mathrm{CH}_{3} \mathrm{CN}$ & $\mathrm{CuCl}_{3}{ }^{-}$in $\mathrm{CH}_{2} \mathrm{Cl}_{2}$ & $\mathrm{NEt}_{4} \mathrm{CuCl}_{3}$ in $\mathrm{CH}_{2} \mathrm{Cl}_{2}$ \\
\hline \multicolumn{6}{|c|}{ Calculated Results } \\
\hline $2428(0.0003)$ & $2495(0.0003)$ & $2503(0.0005)$ & $1572(0.0006)$ & $2715(0.0000)$ & $2552(0.0000)$ \\
\hline $2428(0.0003)$ & $2483(0.0003)$ & $2403(0.0003)$ & $1483(0.0004)$ & $1669(0.0000)$ & $1641(0.0000)$ \\
\hline $1977(0.0003)$ & $2013(0.0003)$ & $2002(0.0003)$ & $1173(0.0009)$ & $1573(0.0000)$ & $1497(0.0000)$ \\
\hline $1391(0.0000)$ & $1405(0.0000)$ & $1386(0.0000)$ & $1050(0.0000)$ & $1421(0.0003)$ & $1371(0.0003)$ \\
\hline $442(0.0000)$ & $443(0.0000)$ & $449(0.0001)$ & $487(0.0064)$ & $463(0.0222)$ & $465(0.0249)$ \\
\hline $419(0.0141)$ & $420(0.0143)$ & $433(0.0093)$ & $435(0.0089)$ & $401(0.0000)$ & $399(0.0001)$ \\
\hline $419(0.0142)$ & $420(0.0144)$ & $426(0.0207)$ & $396(0.0178)$ & $380(0.0002)$ & $385(0.0002)$ \\
\hline $360(0.0039)$ & $360(0.0042)$ & $371(0.0028)$ & $381(0.0016)$ & $374(0.0000)$ & $380(0.0000)$ \\
\hline $341(0.0001)$ & $341(0.0003)$ & $357(0.0013)$ & $365(0.0012)$ & $357(0.0119)$ & $366(0.0096)$ \\
\hline $340(0.0002)$ & $341(0.0002)$ & $350(0.0008)$ & $344(0.0005)$ & $343(0.0384)$ & $343(0.0360)$ \\
\hline $338(0.0000)$ & $338(0.0000)$ & $344(0.0005)$ & $314(0.0755)$ & $306(0.0172)$ & $311(0.0166)$ \\
\hline $318(0.0000)$ & $319(0.0000)$ & $331(0.0002)$ & $292(0.0560)$ & $277(0.0327)$ & $276(0.0266)$ \\
\hline $298(0.0544)$ & $298(0.0554)$ & $307(0.0590)$ & $260(0.0325)$ & $248(0.0581)$ & $250(0.0601)$ \\
\hline $297(0.0544)$ & $297(0.0551)$ & $298(0.0684)$ & & & \\
\hline $273(0.0000)$ & $273(0.0000)$ & $277(0.0004)$ & & & \\
\hline $241(0.0414)$ & $241(0.0433)$ & $244(0.0326)$ & & & \\
\hline \multicolumn{6}{|c|}{ Experimental Results } \\
\hline 460 (shoulder) & 460 (shoulder) & & 350 & 350 & \\
\hline 407 & 411 & & 465 & 470 & \\
\hline 345 (shoulder) & 345 (shoulder) & & & & \\
\hline 294 & 295 & & & & \\
\hline 241 & 241 & & & & \\
\hline
\end{tabular}

${ }^{a}$ The computed oscillator strength values are shown in parentheses. The vertical transitions observed in the experiment are marked in bold. 
are internal conversion to the ground state through the manifold of lower-lying ligand-field excited states, ionic dissociation into a $\left[\mathrm{CuCl}_{3}\right]^{-}$complex and a $\mathrm{Cl}^{-}$ion, and radical dissociation into a $\left[\mathrm{CuCl}_{3}\right]^{2-}$ complex and a chlorine atom. The ionic dissociation is the major reaction channel for $\left[\mathrm{CuCl}_{4}\right]^{2-}$ complexes in the LMCT excited states. Indeed, quantum yields of the formation of copper(I) complexes, products of the radical dissociation do not exceed $0.5 \%^{32,44}$ and are significantly smaller than quantum yields of the formation of the ionic dissociation products. However, due to high lability intrinsic to copper(II) complexes the ionic dissociation products quickly recombine to re-form the parent complexes, whereas the radical dissociation products undergo further reactions forming long-lived photoreduction products, which include stable copper(I) complexes.

Excitation at $420 \mathrm{~nm}$ predominantly causes the ${ }^{2} E_{\mathrm{Cl}(\mathrm{n}) \rightarrow \mathrm{Cu}\left(\mathrm{d}_{x y}\right)}$ LMCT transition in the $\left[\mathrm{CuCl}_{4}\right]^{2-}$ complex. $^{33}$ The populated Franck-Condon LMCT state is repulsive, leading to the $\mathrm{Cu}-\mathrm{Cl}$ bond breaking and the formation of copper(II) trichloro complex and chloride ion products. ${ }^{32,33}$ In the previous studies, the 20 ps to $1 \mathrm{~ns}$ transient absorption spectra of $\left[\mathrm{CuCl}_{4}\right]^{2-}$ in acetonitrile were assigned to the formation of the $\left[\mathrm{CuCl}_{3} \mathrm{CH}_{3} \mathrm{CN}\right]^{-}$product of ionic dissociation (eqs 6 and 7): ${ }^{32,33}$

$$
\begin{aligned}
& {\left[\mathrm{Cu}^{\mathrm{II}} \mathrm{Cl}_{4}\right]^{2-} \stackrel{420 \mathrm{~nm}}{\longrightarrow}\left[\mathrm{Cu}^{\mathrm{II}} \mathrm{Cl}_{3}\right]^{-}+\mathrm{Cl}^{-}} \\
& {\left[\mathrm{Cu}^{\mathrm{II}} \mathrm{Cl}_{3}\right]^{-}+\mathrm{CH}_{3} \mathrm{CN} \stackrel{<20 \mathrm{ps}}{\longrightarrow}\left[\mathrm{Cu}^{\mathrm{II}} \mathrm{Cl}_{3} \mathrm{CH}_{3} \mathrm{CN}\right]^{-}}
\end{aligned}
$$

The lack of change of the $\Delta A$ spectra after 20 ps demonstrates that the initially formed $\left[\mathrm{CuCl}_{3}\right]^{-}$complexes react with the acetonitrile solvent molecules well within the first 20 ps after excitation, forming the $\left[\mathrm{CuCl}_{3} \mathrm{CH}_{3} \mathrm{CN}\right]^{-}$complexes. This conclusion agrees with the DFT calculations, which demonstrate that the reaction between $\left[\mathrm{CuCl}_{3}\right]^{-}$and acetonitrile has no potential energy barrier, Figure 7 . The exact built-up time constant of $\left[\mathrm{CuCl}_{3} \mathrm{CH}_{3} \mathrm{CN}\right]^{-}$cannot be determined because the short-time $\Delta A$ spectra are dominated by intense ligand-field excited-state absorption. ${ }^{32,33}$ The 20 ps to $1 \mathrm{~ns} \Delta A$ spectra of dichloromethane solutions are similar to those in acetonitrile solutions, albeit with a small solvatochromic shift of the $465 \mathrm{~nm}$ band to $470 \mathrm{~nm}$, and can analogously be assigned to ligand loss by $\left(\mathrm{NEt}_{4}^{+}\right)_{2}\left(\mathrm{CuCl}_{4}^{2-}\right)$ with the formation of $\left(\mathrm{NEt}_{4}^{+}\right)\left(\mathrm{CuCl}_{3}{ }^{-}\right)$. On the basis of the DFT calculations, the formation of $\left(\mathrm{NEt}_{4}^{+}\right)\left(\mathrm{CuCl}_{3} \mathrm{CH}_{2} \mathrm{Cl}_{2}^{-}\right)$complexes is unlikely. The spectral shape of the nanosecond $\Delta A$ spectra is similar to the shape of the picosecond $\Delta A$ spectra in both acetonitrile and dichloromethane, Figure 3. This observation is evidence that starting from 20 ps up to several microseconds, the product copper(II) species exist in the single form in these two solvents, $\left[\mathrm{CuCl}_{3} \mathrm{CH}_{3} \mathrm{CN}\right]^{-}$and $\left(\mathrm{NEt}_{4}^{+}\right)\left(\mathrm{CuCl}_{3}^{-}\right)$. The positive $\Delta A$ bands decay single-exponentially to the zero signal level concurrently with the ground-state bleach recovery and without spectral shape change, revealing a single process, namely, the recombination reaction of copper(II) trichloro complexes and chloride ions into parent copper(II) tetrachloro complexes (eqs 2 and 8$)$ :

$$
\left[\mathrm{NEt}_{4}\right]\left[\mathrm{CuCl}_{3}\right]+\mathrm{NEt}_{4} \mathrm{Cl}=\left[\mathrm{NEt}_{4}\right]_{2}\left[\mathrm{CuCl}_{4}\right]
$$

The recombination pseudo-first-order rate constants linearly depend on the concentration of $\mathrm{NEt}_{4} \mathrm{Cl}$, Figure 6:

$$
k_{\mathrm{obs}}=k_{\mathrm{q}} \cdot\left[\mathrm{NEt}_{4} \mathrm{Cl}\right]
$$

The bimolecular rate constants, $k_{\mathrm{q}}$, are equal to $(9.0 \pm 0.1) \times$ $10^{7}$ and $(5.3 \pm 0.4) \times 10^{8} \mathrm{M}^{-1} \mathrm{~s}^{-1}$ in acetonitrile and dichloromethane, respectively. These values are about 2 orders smaller than the diffusion-controlled rate constants, $8.3 \times 10^{9}$ and $1.6 \times 10^{10} \mathrm{M}^{-1} \mathrm{~s}^{-1}$ estimated in acetonitrile and dichloromethane, respectively, Table 1 , implying that the corresponding recombination reactions in both the solvents are controlled by potential energy barriers.

In acetonitrile, the recombination reaction of copper(II) trichloro complexes and chloride ions to parent $\left[\mathrm{CuCl}_{4}\right]^{2-}$ complexes, eq 2 , occurs via ligand exchange. The large bimolecular rate constant of this ligand exchange, $9.0 \times 10^{7}$ $\mathrm{M}^{-1} \mathrm{~s}^{-1}$, demonstrates that the copper(II) chloro complexes are highly labile in acetonitrile. ${ }^{7}$ The observation that the ligand recombination rate constant linearly depends on the concentration of the incoming ligand, the chloride ion, implies that the ligand exchange reaction (eq 2) proceeds either through the associative or associative interchange mechanisms (eqs 4a,b). In our experiments, only the single form of copper(II) trichloro complex is observed whereas intermediate species are not kinetically detected, which leads to the conclusion that ligand exchange between a $\left[\mathrm{CuCl}_{3} \mathrm{CH}_{3} \mathrm{CN}\right]^{-}$complex and a $\mathrm{Cl}^{-}$ion is described by the associative interchange mechanism. The proposed mechanism is supported by the DFT calculations. In both the associative and dissociative mechanisms (eqs 3a,b and $4 a, b)$, the first steps, which, correspondingly, are addition of the chloride ion and elimination of the acetonitrile molecule, are rate-limiting as they are controlled by large potential energy barriers ( 30.5 and $54.5 \mathrm{~kJ} \mathrm{~mol}^{-1}$, respectively, Figures 7 and 8). As a result, for the ligand exchange reaction between a $\left[\mathrm{CuCl}_{3} \mathrm{CH}_{3} \mathrm{CN}\right]^{-}$complex and $\mathrm{C}^{-}$ion the associative mechanism is favorable.

In dichloromethane, recombination of copper(II) trichloro complexes and chloride ions to parent copper(II) tetrachloro complexes (eq 5) is a simple one-step addition reaction. According to the DFT calculations, the potential energy barrier for this reaction is $25.0 \mathrm{~kJ} \mathrm{~mol}^{-1}$, Figure 10 . Thus, the potential energy barriers for recombination of copper(II) trichloro complexes and chloride ions into copper(II) tetrachloro complexes are 30.5 and $25.0 \mathrm{~kJ} \mathrm{~mol}^{-1}$ in acetonitrile and dichloromethane, respectively. This trend is in agreement with the experimental recombination rate constants being larger in dichloromethane $\left(5.3 \times 10^{8} \mathrm{M}^{-1} \mathrm{~s}^{-1}\right)$ than in acetonitrile $(9.0 \times$ $\left.10^{7} \mathrm{M}^{-1} \mathrm{~s}^{-1}\right)$ because lowering the energy barrier typically accelerates the reaction. Slower recombination in acetonitrile than in dichloromethane can be explained by steric/geometrical factors. The addition of a chloride ion to a tricoordinated $\left[\mathrm{CuCl}_{3}\right]^{-}$in dichloromethane (eq 5) does not seem to involve significant geometry rearrangement of the reactant species because at the energy maximum, the $\mathrm{CuCl}_{3}$ moiety has the same geometry as in the initial $\left[\mathrm{CuCl}_{3}\right]^{-}$complex. Therefore, the potential energy barrier of the addition arises as the result of columbic repulsion between two negatively charged ions, Figure 10 and Table 3 . At the same time, the potential energy barrier for the addition of a chloride ion to a tetracoordinated $\left[\mathrm{CuCl}_{3} \mathrm{CH}_{3} \mathrm{CN}\right]^{-}$in acetonitrile (eq $4 \mathrm{a}$ ) is due to both columbic repulsion between two negatively charged ions and steric factors because in the maximum energy geometry, the $\mathrm{CuCl}_{3} \mathrm{CH}_{3} \mathrm{CN}$ fragment has a geometry significantly different from that of the initial $\left[\mathrm{CuCl}_{3} \mathrm{CH}_{3} \mathrm{CN}\right]^{-}$complex, Table 4. This implies that additional energy is required for the addition in acetonitrile. 
Table 3. Structural Parameters of the Optimized Geometries of the Reagents, Products, and Potential Energy Maximum of the Recombination Reaction between a Copper(II) Trichloro Complex and a Chloride Ion To Form a Copper(II) Tetrachloro Complex in Dichloromethane ${ }^{a}$

\begin{tabular}{clclc}
\multirow{2}{*}{ bond length, $\AA$} & {$\left[\mathrm{CuCl}_{3}\right]^{-}$} & $\mathrm{Max}_{1}$ & {$\left[\mathrm{CuCl}_{4}\right]^{2-}$} \\
& $\mathrm{Cu}-\mathrm{Cl}_{1}$ & 2.19 & 2.19 & 2.30 \\
& $\mathrm{Cu}-\mathrm{Cl}_{2}$ & 2.20 & 2.21 & 2.31 \\
& $\mathrm{Cu}-\mathrm{Cl}_{3}$ & 2.19 & 2.19 & 2.30 \\
& $\mathrm{Cu}-\mathrm{Cl}_{4}$ & & 4.00 & 2.31 \\
angle, degrees & $\mathrm{Cl}_{1}-\mathrm{Cu}-\mathrm{Cl}_{2}$ & 112.5 & 110.7 & 101.0 \\
& $\mathrm{Cl}_{2}-\mathrm{Cu}-\mathrm{Cl}_{3}$ & 111.8 & 110.8 & 101.0 \\
& $\mathrm{Cl}_{1}-\mathrm{Cu}-\mathrm{Cl}_{3}$ & 135.7 & 136.4 & 128.0 \\
& $\mathrm{Cl}_{1}-\mathrm{Cu}-\mathrm{Cl}_{4}$ & & 89.5 & 101.1 \\
& $\mathrm{Cl}_{2}-\mathrm{Cu}-\mathrm{Cl}_{4}$ & & 108.5 & 128.2
\end{tabular}

${ }^{a}$ All calculations were performed at the B3LYP/6-31G(d)//PCM(dichloromethane) level of theory.

\section{CONCLUSIONS}

The dynamics and underlying reaction mechanisms of the formation of $\mathrm{CuCl}_{4}{ }^{2-}$ complexes from copper(II) $\mathrm{CuCl}_{3}{ }^{-}$ trichloro complexes and chloride ions, the recombination products of ultrafast dissociation of $\mathrm{CuCl}_{4}{ }^{2-}$ promoted into the LMCT excited state upon $420 \mathrm{~nm}$ excitation, are studied in two solvents with different donor properties (acetonitrile and dichloromethane) by means of UV-vis transient absorption when probing from 20 ps to $8 \mu \mathrm{s}$, in conjunction with DFT/ TDDFT calculations. In acetonitrile solutions, the $\mathrm{CuCl}_{3}{ }^{-}$ products rapidly react with the solvent molecule in less than 20 ps to form the $\left[\mathrm{CuCl}_{3} \mathrm{CH}_{3} \mathrm{CN}\right]^{-}$solvato complexes, which then recombine with chloride ions to re-form parent $\left[\mathrm{CuCl}_{4}\right]^{2-}$ complexes. In dichloromethane solutions, $\mathrm{CuCl}_{3}{ }^{-}$products do not form solvato complexes due to weak donor properties of $\mathrm{CH}_{2} \mathrm{Cl}_{2}$ molecules. Instead, they immediately recombine with chloride ions to re-form parent $\left[\mathrm{CuCl}_{4}\right]^{2-}$ complexes. It is important to note that all negatively charged species exist as solvated ions in acetonitrile, but they form ion pairs with $\mathrm{NEt}_{4}{ }^{+}$ counterions in dichloromethane because of low polarity of this solvent. In both the solvents investigated, the recombination rate constants linearly depend on the concentration of $\mathrm{NEt}_{4} \mathrm{Cl}$, the source of chloride ions. The bimolecular rate constants of the recombination, $k_{\mathrm{q}}$, are equal to $(9.0 \pm 0.1) \times 10^{7}$ and $(5.3 \pm 0.4)$ $\times 10^{8} \mathrm{M}^{-1} \mathrm{~s}^{-1}$ in acetonitrile and dichloromethane, respectively, which are about 2 orders of magnitude smaller than diffusioncontrolled rate constants in these solvents, implying that in both cases the recombination reactions are controlled by energy barriers.

In acetonitrile, the recombination reaction between copper(II) trichloro complexes, $\left[\mathrm{CuCl}_{3} \mathrm{CH}_{3} \mathrm{CN}\right]^{-}$, and chloride ions to re-form $\left[\mathrm{CuCl}_{4}\right]^{2-}$ complexes occurs via ligand exchange, which can be interpreted as the associative interchange mechanism with the intermediacy of pentacoordinated complexes, $\left[\mathrm{CuCl}_{4} \mathrm{CH}_{3} \mathrm{CN}\right]^{2-}$ :

$$
\left[\mathrm{CuCl}_{3} \mathrm{CH}_{3} \mathrm{CN}\right]^{-} \stackrel{+\mathrm{Cl}^{-}}{\longrightarrow}\left[\mathrm{CuCl}_{4} \mathrm{CH}_{3} \mathrm{CN}\right]^{2-} \underset{-\mathrm{CH}_{3} \mathrm{CN}}{\longrightarrow}\left[\mathrm{CuCl}_{4}\right]^{2-}
$$

The proposed mechanism is supported by the DFT calculations. The calculated value of the activation energy for the rate-limiting step, which is the addition of $\mathrm{Cl}^{-}$, is about 30.5 $\mathrm{kJ} \mathrm{mol}^{-1}$. In dichloromethane, the recombination of copper(II) trichloro complexes and chloride ions into copper(II) tetrachloro complexes takes place via a simple one-step addition:

$$
\left[\mathrm{CuCl}_{3}\right]^{-}+\mathrm{Cl}^{-} \rightarrow\left[\mathrm{CuCl}_{4}\right]^{2-}
$$

According to our DFT calculations, the potential energy barrier for this reaction is $25.0 \mathrm{~kJ} \mathrm{~mol}^{-1}$. The recombination in acetonitrile requires a larger energy barrier compared with that in dichloromethane due to steric/geometrical factors. This trend correlates to that for the recombination bimolecular rate constants, which are observed to be larger in dichloromethane than in acetonitrile.

\section{ASSOCIATED CONTENT}

\section{Supporting Information}

Supporting Information section contains (1) detailed description of the calculation of diffusion-controlled rate constants, (2) steady-state spectra of copper(II) solutions in acetonitrile and dichloromethane used in transient absorption measurements and

Table 4. Structural Parameters of the Optimized Geometries of the Reagents, Products, and Potential Energy Maxima of the Recombination Reaction between a Copper(II) Trichloro Complex and a Chloride Ion To Form a Copper(II) Tetrachloro

\begin{tabular}{|c|c|c|c|c|c|c|}
\hline & & {$\left[\mathrm{CuCl}_{3} \mathrm{CH}_{3} \mathrm{CN}\right]^{-}$} & $\operatorname{Max}_{1}$ & {$\left[\mathrm{CuCl}_{4} \mathrm{CH}_{3} \mathrm{CN}\right]^{2-}$} & $\operatorname{Max}_{2}$ & {$\left[\mathrm{CuCl}_{4}\right]^{2-}$} \\
\hline \multirow[t]{5}{*}{ bond length, A } & $\mathrm{Cu}-\mathrm{Cl}_{1}$ & 2.28 & 2.36 & 2.34 & 2.33 & 2.31 \\
\hline & $\mathrm{Cu}-\mathrm{Cl}_{2}$ & 2.28 & 2.33 & 2.33 & 2.32 & 2.31 \\
\hline & $\mathrm{Cu}-\mathrm{Cl}_{3}$ & 2.28 & 2.43 & 2.50 & 2.32 & 2.31 \\
\hline & $\mathrm{Cu}-\mathrm{Cl}_{4}$ & & 3.20 & 2.50 & 2.48 & 2.31 \\
\hline & $\mathrm{Cu}-\mathrm{N}$ & 1.96 & 1.97 & 1.96 & 2.66 & \\
\hline \multirow[t]{10}{*}{ angle, degrees } & $\mathrm{Cl}_{1}-\mathrm{Cu}-\mathrm{Cl}_{2}$ & 100.4 & 92.2 & 96.7 & 95.7 & 100.8 \\
\hline & $\mathrm{Cl}_{2}-\mathrm{Cu}-\mathrm{Cl}_{3}$ & 100.4 & 92.6 & 116.6 & 135.5 & 100.9 \\
\hline & $\mathrm{Cl}_{1}-\mathrm{Cu}-\mathrm{Cl}_{3}$ & 137.2 & 171.7 & 91.4 & 95.6 & 128.7 \\
\hline & $\mathrm{Cl}_{1}-\mathrm{Cu}-\mathrm{Cl}_{4}$ & & 89.6 & 91.1 & 103.3 & 100.8 \\
\hline & $\mathrm{Cl}_{2}-\mathrm{Cu}-\mathrm{Cl}_{4}$ & & 107.0 & 119 & 108.8 & 128.5 \\
\hline & $\mathrm{Cl}_{3}-\mathrm{Cu}-\mathrm{Cl}_{4}$ & & 95.6 & 123.5 & 110 & 100.9 \\
\hline & $\mathrm{Cl}_{1}-\mathrm{Cu}-\mathrm{N}$ & 95.3 & 88.3 & 177.4 & 172.1 & \\
\hline & $\mathrm{Cl}_{2}-\mathrm{Cu}-\mathrm{N}$ & 135.6 & 158.1 & 86.0 & 83.1 & \\
\hline & $\mathrm{Cl}_{3}-\mathrm{Cu}-\mathrm{N}$ & 46.3 & 84.8 & 87.5 & 80.0 & \\
\hline & $\mathrm{Cl}_{4}-\mathrm{Cu}-\mathrm{N}$ & & 94.9 & 87.5 & 84.5 & \\
\hline
\end{tabular}
Complex in Acetonitrile ${ }^{a}$

${ }^{a}$ All calculations were performed at the B3LYP/6-31G(d)//PCM(dichloromethane) level of theory. 
tetraethylammonium chloride solutions in acetonitrile, and (3) Cartesian coordinates of the optimized geometries of copper(II) chloro complexes and corresponding energies of potentialenergy minima and maxima. The Supporting Information is available free of charge on the ACS Publications website at DOI: 10.1021/acs.jpcb.5b03889.

\section{AUTHOR INFORMATION}

\section{Corresponding Author}

*A. S. Mereshchenko. E-mail: andreym@chem.spbu.ru. Phone: +7-951-677-5465.

\section{Author Contributions}

The manuscript was written through contributions of all authors. All authors have given approval to the final version of the manuscript.

\section{Funding}

Saint-Petersburg State University, National Science Foundation, Russian Foundation for Basic Research, Ohio Supercomputer Center.

\section{Notes}

The authors declare no competing financial interest.

\section{ACKNOWLEDGMENTS}

A.S.M. and M.S.P. acknowledge the Saint-Petersburg State University for the financial support (postdoctoral fellowships No. 12.50.1562.2013 and 12.50.1189.2014). M.Yu.S. acknowledges Saint-Petersburg State University for the financial support in framework of Event 6, grant 12.42.1270.2014. Optical measurements were performed at the Center for Optical and Laser Materials Research of the Saint-Petersburg State University and the Center for Photochemical Sciences, Bowling Green State University. Calculations were carried out at the Saint-Petersburg State University Computer Center and the Ohio Supercomputer Center (PCS0204-7). This work was supported by the NSF CAREER (CHE-0847707, A.N.T.), NSF MRI (CHE-0923360, A.N.T.), Saint Petersburg State University research (2015-2017, 12.38.219.2015), and RFBR (14-03-01003 and 15-03-05139) awards.

\section{REFERENCES}

(1) Hervas, M.; Navarro, J. A.; Diaz, A.; Bottin, H.; De la Rosa, M. A. Laser-Flash Kinetic Analysis of the Fast Electron Transfer from Plastocyanin and Cytochrome $\mathrm{C}_{6}$ to Photosystem I. Experimental Evidence on the Evolution of the Reaction Mechanism. Biochemistry 1995, 34, 11321-11326.

(2) Rasmussen, M.; Minteer, S. D. Investigating the Mechanism of Thylakoid Direct Electron Transfer For Photocurrent Generation. Electrochim. Acta 2014, 126, 68-73.

(3) Ranieri, A.; Battistuzzi, G.; Borsari, M.; Casalini, S.; Fontanesi, C.; Monari, S.; Siwek, M. J.; Sola, M. Thermodynamics and Kinetics of the Electron Transfer Process of Spinach Plastocyanin Adsorbed on a Modified Gold Electrode. J. Electroanal. Chem. 2009, 626, 123-129.

(4) Olloqui-Sariego, J. L.; Moreno-Beltran, B.; Diaz-Quintana, A.; De la Rosa, M.; Calvente, J. J.; Andreu, R. Temperature-Driven Changeover in the Electron-Transfer Mechanism of a Thermophilic Plastocyanin. J. Phys. Chem. Lett. 2014, 5, 910-914.

(5) Solomon, E. I.; Szilagyi, R. K.; George, S. D.; Basumallick, L. Electronic Structures of Metal Sites in Proteins and Models: Contributions to Function in Blue Copper Proteins. Chem. Rev. 2004, 104, 419-458.

(6) Nagasawa, Y.; Fujita, K.; Katayama, T.; Ishibashi, Y.; Miyasaka, H.; Takabe, T.; Nagao, S.; Hirota, S. Coherent Dynamics and Ultrafast Excited State Relaxation of Blue Copper Protein; Plastocyanin. Phys. Chem. Chem. Phys. 2010, 12, 6067-6075.
(7) Richens, D. T. Ligand Substitution Reactions at Inorganic Centers. Chem. Rev. 2005, 105, 1961-2002.

(8) Vafazadeh, R.; Bidaki, S. Kinetics and Mechanism of Ligand Exchange Reaction of Copper(II) Complexes with Tetradentate Schiff Base Ligands. Acta Chim. Slov. 2014, 61, 153-160.

(9) Helm, L.; Merbach, A. E. Inorganic and Bioinorganic Solvent Exchange Mechanisms. Chem. Rev. 2005, 105, 1923-1959.

(10) Cui, X.; Khlobystov, A. N.; Chen, X.; Marsh, D. H.; Blake, A. J.; Lewis, W.; Champness, N. R.; Roberts, C. J.; Schröder, M. Dynamic Equilibria in Solvent-Mediated Anion, Cation and Ligand Exchange in Transition-Metal Coordination Polymers: Solid-State Transfer or Recrystallisation. Chem. - Eur. J. 2009, 15, 8861-8873.

(11) Rotzinger, F. P. Treatment of Substitution and Rearrangement Mechanisms of Transition Metal Complexes with Quantum Chemical Methods. Chem. Rev. 2005, 105, 2003-2037.

(12) Maigut, J.; Meier, R.; Zahl, A.; van Eldik, R. Effect of Chelate Dynamics on Water Exchange Reactions of Paramagnetic Aminopolycarboxylate Complexes. Inorg. Chem. 2008, 47, 5702-5719.

(13) Ma, H.; Wan, C.; Zewail, A. H. Dynamics of Ligand Substitution in Labile Cobalt Complexes Resolved by Ultrafast T-Jump. Proc. Natl. Acad. Sci. U. S. A. 2008, 105, 12754-12757.

(14) Schwenk, C. F.; Loeffler, H. H.; Rode, B. M. Structure and Dynamics of Metal Ions in Solution: QM/MM Molecular Dynamics Simulations of $\mathrm{Mn}^{2+}$ and $\mathrm{V}^{2+}$. J. Am. Chem. Soc. 2003, 125, 1618-1624.

(15) Kawamura, K.; Igarashi, S.; Yotsuyanagi, T. Kinetics of the Accelerator Ligand Effect for the Complex Formation of Cd(II) Ion with a Cationic Water-Soluble Porphyrin. Inorg. Chim. Acta 2007, 360, 3287-3295.

(16) Rode, B. M.; Schwenk, C. F.; Hofer, T. S.; Randolf, B. R. Coordination and Ligand Exchange Dynamics of Solvated Metal Ions. Coord. Chem. Rev. 2005, 249, 2993-3006.

(17) Vos, J. G.; Pryce, M. T. Photoinduced Rearrangements in Transition Metal Compounds. Coord. Chem. Rev. 2010, 254, 25192532.

(18) Taube, H. Rates and Mechanisms of Substitution in Inorganic Complexes in Solution. Chem. Rev. 1952, 50, 69-126.

(19) Langford, C. H.; Gray, H. B. Ligand Substitution Processes; W. A. Benjamin, Inc.: New York, 1965.

(20) Ohtaki, H. Structural Studies on Solvation and Complexation of Metal Ions in Nonaqueous Solutions. Pure Appl. Chem. 1987, 59, 11431150.

(21) Ishiguro, S.; Jeliazkova, B. G.; Ohtaki, H. Complex Formation and Solvation of $\left(\mathrm{CuCl}_{\mathrm{n}}\right)^{(2-\mathrm{n})+}$ in Acetonitrile and in N,N-dimethylformamide. Bull. Chem. Soc. Jpn. 1985, 58, 1749-1754.

(22) Khan, M.; Bouet, G.; Vierling, F.; Meullemeestre, J.; Schwing, M.J. Formation of Cobalt(II), Nickel(II) and Copper(II) Chloro Complexes in Alcohols and the Irving-Williams Order of Stabilities. Transition Met. Chem. 1996, 21, 231-234.

(23) Khan, M. A.; Meullemeestre, J.; Schwing, M. J.; Vierling, F. Detailed Spectrophotometric Study of the Copper(II) Halides in Anhydrous Methanol. Inorg. Chem. 1989, 28, 3306-3309.

(24) Kudrev, A. G. Calculation of the Equilibrium Constants and Cooperative Parameters of Formation of $\mathrm{Cu}$ (II) Chloride Complexes in Nonaqueous Solvents. Russ. J. Coord. Chem. 2010, 36, 704-710.

(25) Helm, L.; Lincoln, S. F.; Merbach, A. E.; Zbinden, D. Solvent Exchange in Hexakis(methanol)copper(II) Ion. Oxygen-17 NMR Variable-Temperature, Pressure, and Frequency Study. Inorg. Chem. 1986, 25, 2550-2552.

(26) Eigen, M.; Wilkins, R. G. The Kinetics and Mechanism of Formation of Metal Complexes. Adv. Chem. Ser. 1965, 49, 55-80.

(27) Mereshchenko, A. S.; Pal, S. K.; Karabaeva, K. E.; El-Khoury, P. Z.; Tarnovsky, A. N. Photochemistry of Monochloro Complexes of Copper(II) in Methanol Probed by Ultrafast Transient Absorption Spectroscopy. J. Phys. Chem. A 2012, 116, 2791-2799.

(28) Maigut, J.; Meier, R.; Zahl, A.; van Eldik, R. Triggering Water Exchange Mechanisms via Chelate Architecture. Shielding of Transition Metal Centers by Aminopolycarboxylate Spectator Ligands. J. Am. Chem. Soc. 2008, 130, 14556-14569. 
(29) Houston, J. R.; Richens, D. T.; Casey, W. H. Distinct WaterExchange Mechanisms for Trinuclear Transition-Metal Clusters. Inorg. Chem. 2006, 45, 7962-7967.

(30) Caër, S. L.; Mestdagh, H.; Maître, P. Condensation Reaction vs. Ligand Exchange with First-Row Transition Metal Cations: A Theoretical Study of $\mathrm{Cu}^{+}$Heteroleptic Model Complexes. Int. J. Mass Spectrom. 2003, 227, 587-600.

(31) Ma, H.; Wan, C.; Zewail, A. H. Ultrafast T-Jump in Water: Studies of Conformation and Reaction Dynamics at the Thermal Limit. J. Am. Chem. Soc. 2006, 128, 6338-6340.

(32) Mereshchenko, A. S.; Olshin, P. K.; Karimov, A. M.; Skripkin, M. Yu.; Burkov, K. A.; Tveryanovich, Yu. S.; Tarnovsky, A. N. Photochemistry of Copper(II) Chlorocomplexes in Acetonitrile: Trapping the Ligand-to-Metal Charge Transfer Excited State Relaxations Pathways. Chem. Phys. Lett. 2014, 615, 105-110.

(33) Mereshchenko, A. S. Ultrafast Photochemistry of Polyatomic Molecules Containing Labile Halogen Atoms in Solution. Ph.D. Thesis, Bowling Green State University, Bowling Green, OH, 2013.

(34) CRC Handbook of Chemistry and Physics, 90th ed.; Lide, D. R., Ed.;

CRC Press (Taylor and Francis Group): Boca Raton, FL, 2009.

(35) Frisch, M. J.; et al. Gaussian 09, Revision A.02; Gaussian, Inc.: Wallingford, CT, 2009.

(36) Ferguson, J. Electronic Absorption Spectrum and Structure of $\mathrm{CuCl}_{4}{ }^{2}$. J. Chem. Phys. 1964, 40, 3406-3410.

(37) Furlani, C.; Morpurgo, G. Properties and Electronic Structure of Tetrahalogenocuprate (II)-Complexes. Theor. Chim. Acta 1963, 1, 102115.

(38) Rice, S. A. In Diffusion-Limited Reactions; Bamford, C. H., Tipper, C. F. H., Compton, R. G., Eds.; Comprehensive Chemical Kinetics; Elsevier: Amsterdam, 1985; Vol. 25, pp 3-46.

(39) Doyle, K. J.; Tran, H.; Baldoni-Olivencia, M.; Karabulut, M.; Hoggard, P. E. Photocatalytic Degradation of Dichloromethane by Chlorocuprate(II) Ions. Inorg. Chem. 2008, 47, 7029-7034.

(40) Golubeva, E. N.; Zubanova, E. M.; Melnikov, M. Y.; Gostev, F. E.; Shelaev, I. V.; Nadtochenko, V. A. Femtosecond Spectroscopy and TDDFT Calculations of $\mathrm{CuCl}_{4}^{2-}$ Excited States. Dalt. Trans. 2014, 43, 17820-17827.

(41) Grimsrud, E. P.; Kratochvil, B. Second-Order Rate Constants and Ion Association in Aprotic Solvents by High-Precision Conductance. J. Am. Chem. Soc. 1973, 95, 4477-4483.

(42) Bait, S.; du Chattel, G.; de Kieviet, W.; Tieleman, A. Ion Association and Solvation in Dichloromethane of Tetrachloro- and Tetrabromoferrates(III) Compared with Simple Halides. Z. Naturforsch., B: J. Chem. Sci. 1978, 33, 745-749.

(43) Gromov, O. I.; Zubanova, E. M.; Golubeva, E. N.; Plyusnin, V. F.; Zhidomirov, G. M.; Melnikov, M. Y. UV-Vis Identification and DFTAssisted Prediction of Structures of $\mathrm{Cu}(\mathrm{II})-$ Alkyl Chlorocomplexes. J. Phys. Chem. A 2012, 116, 11581-11585.

(44) Cervone, E.; Camassei, F. D.; Giannini, I.; Sykora, J. Photoredox Behaviour of Chlorocopper(II) Complexes in Acetonitrile: Mechanism and Quantum Yields. J. Photochem. 1979, 11, 321-332. 